\title{
Sustainable Development and the Need for Effective Security for Road Travellers in Nigeria
}

\author{
C. C. Ojinma ${ }^{1}$, P.E.N. Okoroafor ${ }^{2}$ And I.S. Umo ${ }^{3}$ \\ Department of Geography and Environment Studies, Alvan Ikoku Federal College of Education, Owerri.
}

\begin{abstract}
Through the Nigerian police outfit is criticized in today's society, the security of the nation especially road travelers falls squarely on their shoulders. This is important because, road travelers most often, constitute the highly trained and built manpower of the country. As a result of the composition of these travelers, sustainability of the development rests on the vigilance and security. This is because the travelers that they protect are the sustainers of development. They are the users of resources and the maintainers of the environment for tomorrow. This work looks at the efficiency and effectiveness of road security for travelers. The methodology is empirical, supported with some secondary sources. It examines the discharge of Police duties to road travelers, who constitute the manpower for the sustainable development. Our conclusion and recommendations will facilitate service delivery through effective policing for road travelers.

Keywords: Sustainable Development, Effective Security, Road Travellers.
\end{abstract}

\section{Introduction}

Most often, discusses or sustainable development have concentrated on the use of resources-physical and/or economical. This is usually with the understanding that such use of resources must be so oriented as to provide for the needs of today's population and leave a room for tomorrow's generation.

One area of sustainable development that has not been given much attention in development literature is the issue of the human capital or resource, in terms of their development and preservation of what has been developed. It is in this connection that this paper intends to analyse the security of road travelers - who constitute the developing and developed manpower for the implementation of policies for sustainable development. The basic issues that we shall consider in this paper includes: The capacity of road travelers in Nigeria; the public and travellers' perception of road security and security outfits; police outfit and road security and recommendations towards more effective road security in Nigeria.

\section{Road Travellers In Nigeria}

Since the drastic reduction of rail travel in Nigeria due to various factors, major of which are lack of repairs and modernization of coaches and tracks, coupled with the limitedness of air and water means of travels, road travel has dominated all travels in Nigeria. The implication is that majority of journeys are accomplished, using the various modes of motorcycles, tricycles, cars, light goods and passenger vehicles Heavy goods vehicles, and luxurious buses. These vehicles ply the various routes and these routes are in various states and conditions of repairs.

As a result of the high volumes of traffic experienced on the road medium of transport, various security issues are witnessed.

Generally, the travelers from Imo State travel to various destinations in the country and the disaggregation of these travelers indicates that they are composed of various levels of trained and untrained human capacity or manpower.

\section{The Data}

Our data consists of both quantitative and qualitative information. Quantitatively, we constructed two hundred and forty questionnaires include, Peace Mass transporters; ABC lines; Imo Transport Company (ITC line); Bestway/Constant transport Companies; The Young transport and Abia lines.

The respondents consist of 104 (43.3\% males and 136 (56.7\%) females. Most of the travelers interviewed (87\%) have travelled to their destinations before the journey of interview, so are aware of the events on their routes. About $98.3 \%$ are educated. When disaggregated, we noticed that 3\% had Ph.Ds; $12 \%$ (Msc); $38 \%$ (BSC/HND); $17 \%$ (NCE/OND) and 30\% only obtained their O/Levels. The implication is that the majority of the educated respondents are above ordinary level and must have a fair assessment of the security situation on their routes.

The destinations of the travelers are mostly outside Imo State (92\%), only about twenty (20) respondents were travelling within the state. 
Sustainable Development And The Need For Effective Security For Road Travellers In Nigeria

Table 1: Destinations of Sampled Travellers from Owerri

\begin{tabular}{|c|c|c|c|c|c|c|}
\hline S/No & Destinations & $\begin{array}{l}\text { Within } \\
\text { State }\end{array}$ & Percent-age & $\begin{array}{c}\text { Outside the } \\
\text { State }\end{array}$ & $\begin{array}{l}\text { Percent- } \\
\text { age }\end{array}$ & $\begin{array}{c}\text { Most travelled from } \\
\text { Owerri }\end{array}$ \\
\hline 1. & Aba & - & - & 4 & $2 \%$ & \\
\hline 3. & Awka & - & - & 20 & $8 \%$ & $4^{\text {th }}$ ranked travelled \\
\hline 4. & Bauchi & - & - & 4 & $2 \%$ & \\
\hline 6. & Calabar & - & - & 4 & $2 \%$ & \\
\hline 7. & Enugu & - & - & 36 & $15 \%$ & $2^{\text {nd }}$ ranked travelled \\
\hline 8. & Ekwulobia & - & - & 4 & $2 \%$ & \\
\hline 9. & Lagos & - & - & 24 & $10 \%$ & $3^{\text {rd }}$ ranked travelled \\
\hline 10. & Nsukka & - & - & 8 & $3 \%$ & \\
\hline 13. & Onitsha & - & - & 8 & $3 \%$ & \\
\hline 14. & Port-Harcourt & - & - & 20 & $8 \%$ & $4^{\text {th }}$ ranked travelled \\
\hline 15. & Sokoto & - & - & 8 & $3 \%$ & \\
\hline 16. & Umuahia & - & - & 8 & $3 \%$ & \\
\hline 17. & Uyo & - & - & 40 & $17 \%$ & $1^{\text {st }}$ ranked travelled \\
\hline \multirow[t]{2}{*}{18.} & Warri & - & - & 12 & $5 \%$ & \\
\hline & TOTAL & 20 & 8 & 220 & $92 \%$ & \\
\hline
\end{tabular}

Source: Fieldwork 2012

Table 2: ROAD CRASH STATISTICS - 2008-2011 ON IMO STATE ROADS.

\begin{tabular}{|c|c|c|c|c|}
\hline Year & Total crash & Injured & Killed & Total causality \\
\hline 2008 & 270 & 573 & 165 & 738 \\
\hline 2009 & 182 & 480 & 85 & 704 \\
\hline 2010 & 273 & 781 & 74 & 789 \\
\hline 2011 & 349 & 959 & 97 & 1056 \\
\hline 2012 (Jan.-May) & 155 & 380 & 55 & 489 \\
\hline TOTAL & $\mathbf{1 2 2 9}$ & $\mathbf{3 1 7 3}$ & $\mathbf{4 7 6}$ & $\mathbf{3 7 7 6}$ \\
\hline
\end{tabular}

Source: FRSC, RS 9.4-9.45 (Imo State Command) - 2012

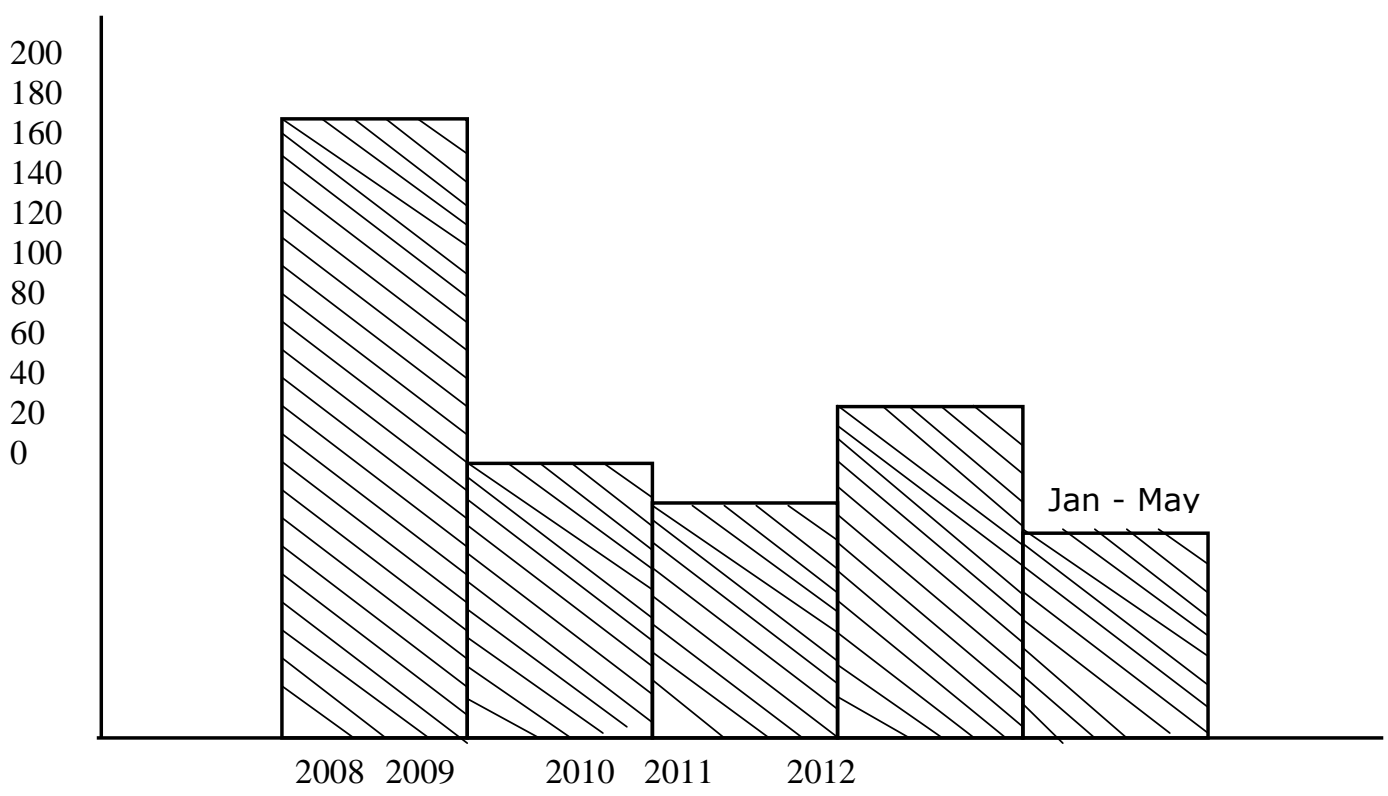

Source: FRSE, Imo State, 2012.

Fig. 1: Graph of number of persons killed in road-crash in Imo State (2008-2011). 
From the table 1, there is a general view of the security state of the roads in Nigeria, since the travelers are spatially distributed to the various parts of the country. Again, the table coupled with the high level of travelers indicate that most of the travelers consists of the highly trained manpower, within the country $-53 \%$ of the respondents (B.Sc and above). The need therefore to ensure security to protect this caliber of manpower cannot be overemphasized especially as road travel appears to be the popular means in Nigeria, today.

\section{Nigerian Roads and Security of Travellers}

An analysis of crash statistics on Nigerian roads between 2008 and 2011 (May 2012) shows that Imo State roads are replete with high casualty figures. According to table 2 and figure I, from 2008 to 2011, there were 3,776 casualties on Imo State roads. Out of this figure, 3,173 persons were injured while 476 persons died. The crash figure is about 1,229 vehicles. Infact, in 2012 alone (Jan - May) there have been 489 accidents on Imo State roads, out of which 55 persons have died and 380 persons injured. Indeed, the half year figure for 2012 is almost the years figure for 2009.

The implication of the above observation is that the levels of crashes on Nigerian roads are still unacceptable. The gory picture is especially imagined when the Imo State figures are projected for the 36 states of the country - Nigeria, including the FCT. For instance, an average for the 4 years (2008-2011) on the number of person killed due to road accidents and projected for the country, means that road accident claims about 3,780 persons annually. This is apart from the high rate of injuries sustained by travelers on the various roads, and some of these injuries are permanent.

Apart from road accidents, the respondents identified various security issues on Nigerian roads. These are outlined on table3.

Table 3: Security Issues on Nigerian Roads

\begin{tabular}{|l|l|c|c|c|}
\hline S/No & \multicolumn{1}{|c|}{ Security Labels } & $\begin{array}{c}\text { No. of } \\
\text { Respondents }\end{array}$ & Percentage (\%) & Ranking \\
\hline 1. & Accidents & 26 & 10.8 & $4^{\text {th }}$ \\
\hline 2. & Armed robbery & 40 & 17.8 & $1^{\text {st }}$ highest ranked \\
\hline 3. & Kidnapping & 35 & 15.7 & $2^{\text {nd }}$ \\
\hline 4. & Car-hijacking & 20 & 8.4 & $6^{\text {th }}$ \\
\hline 5. & Bad roads & 30 & 12.3 & $3^{\text {rd }}$ \\
\hline 6. & Street trading & 12 & 5.0 & $7^{\text {th }}$ \\
\hline 7. & Reckless driving & 15 & $6^{\text {th }}$ & $8^{\text {th }}$ lowest ranked \\
\hline 8. & Faulty traffic lights & 10 & 4.2 & $7^{\text {th }}$ \\
\hline 9. & Illiteracy & 12 & 5.0 & 10.4 \\
\hline 10. & Bad vehicles/overloading & 25 & $5^{\text {th }}$ & $6^{\text {th }}$ \\
\hline 11. & Assassinations & 15 & $\mathbf{2 4 0}$ \\
\hline
\end{tabular}

Source: Field work-2012

From table 3 , road accidents usually very visible among security issues ranked $4^{\text {th }}$, below, armed robbery, kidnapping and bad roads. However, this is not surprising, as bad roads, faculty traffic lights and even bad faulty and overloading are only causes of road accidents. When our respondents were however asked to rate the level of security on the Nigerian roads, (144) or $60 \%$ of the respondents rated the security situation as "FAIR". This rating is however not in tandem with the general view of Nigerians on the state of security on Nigerian roads. According to the publics comments on security (Punch, 2012) it is said "police is your friend", but many young Nigerians are killed by the police on the streets and roads (Highways).... we need educated people in the police not all these hungry lions". In another observation, Oghale (2012) said "The Nigerian police needs a group of psychiatric doctors to treat them. They are all mad animals in Uniform and on roads, they kill fellow Nigerians because of N20.00 (they) even aid and abate criminals in our society..."

The implication of the Masses' comments as highlighted is that the Nigerian police force is a contributory factor to insecurity on the Nigerian roads. This is even in agreement with the $40 \%$ of our respondents who indicated that the security situation or level on the Nigerian roads is low. These respondents among other things observed that ill-equipped police/security officers and corruption on the part of the police are some of the causes of insecurity on the Nigerian roads.

The next section discusses road security and the security agents on the Nigerian roads.

\section{The Police Outfit and Road Security}

Though, the Nigerian police outfit is often criticized as contributory factors and causative agents of insecurity on Nigerian roads, the fact is that the security of the entire nation especially in non-aggressive situations including road security for all travelers rest squarely on their shoulders. Despite the sometimes uncalled for vituperations poured on the police institution, Ojukwu (2011) indicates that a good picture of the 
police personality should and inter alia "Restraint, Commitment, self-controlled, cool and calculated...approachable and available...assertive, not reactionary...good communicator, patient, diligent, cooperative...responsible." However, Asuquo (2012) has observed that in reality "the reverse seems to be the case".

This is especially evident in the manner that policemen on check points or road blocks bark out orders to fellow Nigerians (not criminals) and how they "point" their guns on travelers on the highways, while discharging their duties. Asuquo, concludes that the "average policeman in Nigeria is unfriendly, perennially angry, haggard (looking), ill-trained, ill equipped and constantly cuts an alienated picture in the eyes of the public". Viewing in the same perception, Akanimo (2012) paints gory pictures of the police providing "access codes" to cooperating drivers to avoid "double taxation" and providing "change" to higher denominations of Naira notes given at check points, which have been described as "business centres".

According to Sunday (2012) the police in Nigeria, has become a beggarly outfit at all levels. Majority of the patrol vehicles in their fleets are gestures of corporate social responsibility and sheer benevolence from philanthropic organizations. Indeed, the gate of a particular police station in a neighbourhood is inscribed "Donated by the welders Association". How can such an beggarly outfit protect the citizens, especially travelers who are expected to make "offerings" and donations to their protectors. Infact, the police and security outfits in Nigeria beg for everything, ranging from sachet water to bread on the highways and for free transport when they travel. They have become an "orphan that eke out a living on charity, he includes. Indeed, supporting the police is noble cause, but the reality is that modern policing has spiraled beyond being dependent on handouts and voluntary/involuntary donations and offerings".

These issues are not too far away from the minds of the legislators in the House of Representatives, when they recently called the police checkpoints "crude method of policing that cause traffic congestions and avoidable road accidents, even regarded as grossly ineffective against crime prevention (Victor and Dele, 2012).

Considering the highlights about the police as a security outfit, it appears that the road security operators are more of the security factors than the controllers of insecurity. The question however remains, why police force in Nigeria is beggarly and discredited, whereas the same police force on missions outside Nigeria are pelted with awards and merits medals. (Okonkwo in Ojukwu 2011). This will be the consideration of the next section of this paper.

\section{Towards Effective Road Security in Nigeria}

Ojukwu has declared that "abroad, the Nigeria police is held in high repute following her efficiency and competency". He even asserted that the Nigeria police outfit sent under the United Nations Peace Missions to different parts of the world often return with heart warming recommendations and awards of excellence. The implication of Ojukwu's assertion is that the Nigeria society and government make the police we see on the roads in Nigeria. If this is true, Nigerians and the government can also change the police on the Nigerian roads to the efficient and aware winning Nigeria police under the U.N. Missions. To do this, is not only necessary but a veritable imperative, given the caliber of travelers on Nigerian roads and their importance as trained manpower to implement policies and programmes for sustainable development.

To achieve this change, there is the need for the following:

i. $\quad$ Change in perception of the Nigeria police outfit.

This change in perception has variously been described as a Mechanism (Mangal, 2008) or as a concept (Gate, 1994) of group dynamics. This is a system where deliberate efforts are made on the part of assessors to perceive the changes in a group positively. In this case the persistent negative perception labeled against an individual or group of individuals in a system (a subsystem) is not allowed to be generalized to label the whole system. It is obvious that "bad eggs" exist in all "crates" of egg; however the bad eggs do not label the whole crate as bad. Therefore a positive group perception can transform the police outfit to inestimable height of service delivery, especially on the Nigeria roads. It could be, after all, that the efficiency and effectiveness of the police outfit on the roads may depend on the feedback they receive from both the travelers and the public.

ii. On the part of the government, Sanda (2004) survey speaks volume. The fact that the causes of corruption in the police outfit is linked to pecuniary issues - poor salary; financial greed and insecurity at retirement, means that the Federal Ministry of Police Affairs and the Police Service Commission must come alive to their responsibilities. This is especially necessary because under the United Nations Responsibilities, where the police is well remunerated in foreign currency, with a saving to return to their families at the end of the service, the Nigeria police is efficient, effective and exemplary.

iii. On the part of the Inspector General's Reform Agenda, the continuous and robust motorized patrol of Federal and State highways should be operationalised to ensure safety and security of travelers.

In view of these observations, the paper recommends in specific terms that: 
i. the police security outfit be properly remunerated, trained and retrained as well as insulated against the occupational hazards through insurance and health schemes for the men officers and their families.

ii. the police service commission should professionalise the force, curb the tendency of governments to replicate the force in various guises and discipline the force ethically. The discipline should especially focus in brutality, extortion and harassment of road users.

iii. Special squads should be operationally trained (rather than rehtorics) to handle the increasing wave of kidnapping; hijacking and new wave of sophisticated armed robberies on the highways.

iv. The Highways should be repaired and maintained, expanded and patrolled to ease journeys at all times throughout the federation.

v. The FRSC should intensify the monitoring of passenger vehicles to fish out reckless drivers and ever loaders on the highways.

vi. Government and its agencies should include police on National and International scholarship schemes in such area like applications in monitoring, detecting and preventing crimes on our roads and the society as a whole.

\section{Conclusion}

Travelers on Nigeria roads are majorly educated manpower, who must be protected and preserved for the implementation of the programmes for sustainable development. If these precautions are not taken, attempts at sustainable use of resources for the well being of today's Nigerians and for future generation will only remain a mirage. Sure the security outfits are the instruments of this preservation especially on the Nigeria roads, the police squad should be properly equipped with sophisticated/modern equipment to enable them offer the best that will ensure the protection of lives and property of the citizenry. When this has been done, then sustainable development of the Nigeria resources will become a reality and the transportation and roads agenda of the Present administration accomplished.

\section{References}

[1] Akimino, A.S. (2012). Who will Tame the Nigerian Police Force. Report yourself-Sahara Reporters Nigerian National News: Jan.

[2] Akimino, A. S.(2012). "Withdrawal of checkpoints from Nigerian roads A bold initiate by the Inspector General of Police". Nigerian National News.

[3] Akimino, A. (2011). "The IGP and Nigeria Police Image". Nigerian Newspapers and Foreign News NBF News May 4.

[4] Emeka, U. (2012). "How corrupt Nigeria Police illegally entice the force with over N53.436 from road block extortion" Highways.

[5] Emmanuel, N. (2012). "Security Challenges and the Reform of Nigeria Police". Punch $1^{\text {st }}$ July.

[6] Gates, A. I. (1994). Element of Social Psychology. New Delhi, Macmillan Books.

[7] Mangal, S.K. (2008). Essentials of Educational Psychology. New Delhi, Prentice-Hall of India.

[8] Oghala (2012). "IG Order Patrol of Federal Highways". Punch April 4.

[9] Ojukwu, E.C.S. (2011). Discovering the Police: An Excursion into Police Personality, Powers, Performance and Prudence. Ibadan: Gold press Ltd.

[10] Okonkwo, S.O. (1966). The Police and the Police in Nigeria. London, Vantage Press.

[11] Sunday, E. (2011). "Which way Forward for the Nigeria Police: Federal or State Police". In Law and Human Rights. Feb. 9.

[12] Victor, O. \& Dele, (2012). "Reps kick Against Return of Police Road Blocks". The Nation, $13^{\text {th }}$ March. 